\title{
Application Of Neo Vernacular Architecture In Tongging Agrotourism Planning
}

\author{
Harisdani, D. D. 1 , Chandra, A. ${ }^{2}$ \\ 1,2 Jurusan Arsitektur, Fakultas Teknik, Universitas Sumatera Utara \\ Jl. Perpustakaan St. J07 Building, Medan, 20155, Indonesia \\ *Email: devin.defriza@usu.ac.id \\ Diterima: 25 Mei 2019 Direvisi: 27 Juni 2019 Online: 22 Juli 2019
}

\begin{abstract}
Chinese in Indonesia as one of the diverse ethnicity had a long story in Medan's development. Even though Chinese has been in Indonesia for a long time, the history of Chinese culture is rarely known by the public. The need for a medium to support this is to preserve the culture and history of Chinese. The inadequate medium for documenting and preserving the cultural history threatens the culture gradually lost in the age so that it needs a museum to document Chinese culture. As one of the local and international tourist destination, it needed a cultural museum with an iconic architectural emphasis of metaphorical form. To achieve the research objectives, the glass box method was used as a research method. With the emphasis form on the museum, it could enriched tourism destination and adding insight of local or international citizen about Chinese culture in Medan.
\end{abstract}

Keywords: architecture, culture, metaphor, museum.

\section{INTRODUCTION}

Indonesia is known as the most diverse ethnicities country. One of the cities that suites as a perfect model of ethnic diversity are Medan city. The people consist of various backgrounds, cultures, ethnicity, and languages making Medan as a poly-ethnic city. Chinese in Medan had a long history in Medan's development which is inseparable from the influence of Chinese culture from the Colonial era to the present. The enculturation process of Chinese culture has enriched Indonesia culture.

Medium for documenting and preserving the cultural history is still barely adequate. The inadequate medium for documenting and preserving the cultural history threatens the culture gradually lost in the age so that it needs a museum to document Chinese culture. As one of the local and international tourist destination, it needs a cultural museum with iconic architecture. Expecting the emphasis of metaphorical form could add a new landmark, enriched the tourism destination and could insight local or international citizen about Chinese culture in Medan

\section{Function and Architectural Theory}

The cultural park is a technical implementation unit in term of development, documentation, exhibition venue and cultural information of a region (Kementrian Pendidikan, 1991). It has a function as (a) place to explore art \& regional culture and also for recreation; (b) collecting, processing, analyzing data and information, evaluating, developing and presenting art and culture; (c) holding competitions, discussions, workshops, cultural arts, development facilities; (d) increasing the appreciation of art and culture; (e) enhancing the professionalism of coaches and art workers; (f) enhancing art and cultural skills; (g) organizing collaborative presentations on artwork; (h) the implementation of documentation of art \& culture, business administration \& community service (Resmawat, 2014). The cultural park's function explained above similar to the museum as a place for the permanent exhibition of objects, such as historical heritage, art, and science; to keep antiquities (KBBI, 2018).

The organizational structure of the cultural park management generally consists of 
(a) Head of Cultural Park which is in charge to lead the implementation of the duties and functions of the cultural park, (b) Sub Division of Administration which is in charge to carry out administrative and household matters, (c) Functional Staffs Group which is in charge to carry out art processing in the implementation of the duties and functions of the cultural park according to their expertise and needs; the group is divided into technical culture and functional staff (Resmawat, 2014)).

The metaphor is a way of understanding a thing as if it were something else so that it could learn a better understanding of a topic or achieving something new of a building/design. The metaphor is classified into tangible(can be felt from visual), intangible(non-visual, abstract concept) and combined metaphor (Antoniades, 1990).

\section{Concept}

Museum has some space requirement that should be considered in a design (De Chiara. J, 1990) (Table 1).

Table 1. Space Requirement for a Museum

The area of the objects of the exhibition in one room requires more wall space than the floor area (Table 2). Room size depends on the size of the painting. A typical human perspective $\left(54^{\circ}\right.$ or $27^{\circ}$ from eye view) can be adjusted to a painting that is well illuminated at a distance of 10 meters. Lighting at the historical objects is important to avoid too many lighthighlighted objects. The shape, structure and surface quality of an important object to be highlighted with excellent lighting and color quality (Neufert, 1980).

Table 2. The Standard of Exhibition Objects

\begin{tabular}{|c|c|}
\hline Objects & Space Standard \\
\hline Painting & $\begin{array}{l}3-5 \mathrm{~m}^{2} \text { area of the } \\
\text { wall }\end{array}$ \\
\hline Sculpture & $\begin{array}{l}6-10 \mathrm{~m}^{2} \text { area of the } \\
\text { floor }\end{array}$ \\
\hline Small Objects & $1 \mathrm{~m}^{2}$ space of a chest \\
\hline
\end{tabular}

\begin{tabular}{|c|c|c|c|}
\hline Zone & $\begin{array}{c}\text { Space } \\
\text { Category }\end{array}$ & Space & The recommended illumination for \\
\hline \multirow{9}{*}{ Public } & \multirow{3}{*}{ Collection } & Exhibition Hall & paintung lignting and otner aisplay items is tSU \\
\hline & & Public Lecturer hall & lux. To highlight an object, an illumination of \\
\hline & & Orientation Room & sen tux can be used and ror items that are \\
\hline & \multirow{6}{*}{$\begin{array}{c}\text { Non - } \\
\text { Collection }\end{array}$} & Lobby & enstive to ingnt, such as on parnings, can use \\
\hline & & Information Room & To fux inumination. Placement and lignting of \\
\hline & & Toilet & effect of glare by protecting obiects with glass \\
\hline & & Retail & (Ganslandt. 1992). Natural lighting in the \\
\hline & & $\begin{array}{l}\text { Food Service } \\
\text { Teather }\end{array}$ & museum can be divided into top lighting and \\
\hline & & Examination Room & lighting through the window. Top lighting use \\
\hline \multirow{14}{*}{$\begin{array}{l}\text { Non - } \\
\text { Public }\end{array}$} & \multirow{5}{*}{ Collection } & Manager Room & light from the top of the palate. The benefits are \\
\hline & & Loading Dock & unaffected by the direction of lighting; a little \\
\hline & & Enrolment Room & glare can illuminate the area widely, unaffected \\
\hline & & Goods Lift & by objects such as trees or buildings outside the \\
\hline & & Workshop & museum. The disadvantage is the heat in the \\
\hline & \multirow{6}{*}{$\begin{array}{c}\text { Non- } \\
\text { Collection }\end{array}$} & Mechanical Room & building and the risk of damage to the object \\
\hline & & Electrical Room & due to water and humidity. Lighting through the \\
\hline & & Security Room & window comes from wall openings. The \\
\hline & & Manager Room & advantage is that it gives a soothing view, the air \\
\hline & & Warehouse & circulation is maintained, the lighting is better in \\
\hline & & Kitchen & many objects (Lynch, 1960). \\
\hline & \multirow{3}{*}{ Security } & Collection Storage & The visitor's activity at the cultural park \\
\hline & & Computer Room & $\begin{array}{l}\text { 1he visitor s activity at the cuitural park } \\
\text { have some pattern denending on who are }\end{array}$ \\
\hline & & Security Equipmen & \\
\hline
\end{tabular}




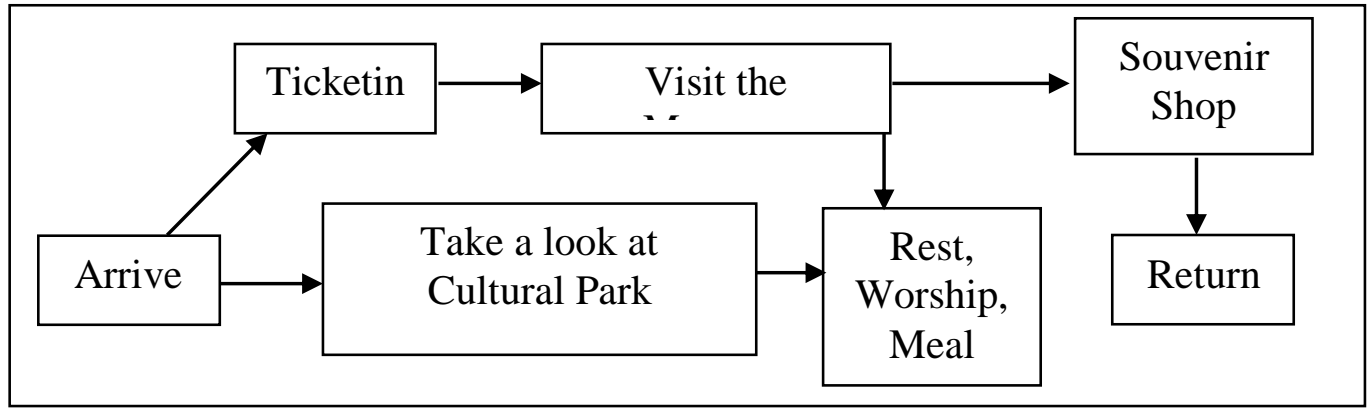

Figure 1. Visitor Activity Pattern Scheme

As for the manager's activity has a simple pattern (Figure 2).

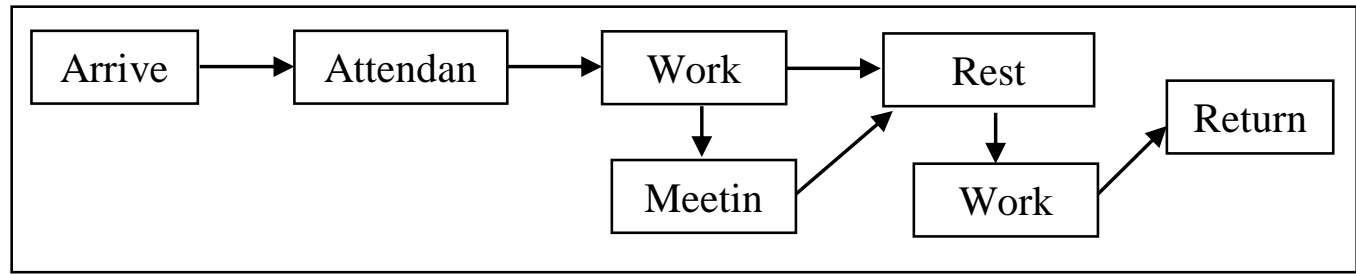

Figure 2. Manager Activity Pattern Scheme

To create an iconic place, there are some elements that should be considered while designing the cultural park in the city. The element of forming city elements consists of (a) Paths are path to move or transmigrate; (b) Edges are limits that can be in the form of a design, river, road, etc.; (c) Districts are part of a city that has special characters or activities; (d) Nodes are nodes where activity meets; (e) Landmarks are symbols that attract visually with the scale in the environment there are differences (Pane \&. Harisdani, 2013). There is also another aspect of creating an iconic place. A place should have an identity. Human role in it will give a different sense to each place. The created sense will form a different character that will distinguish it from other places (Figure 3) (Shirvani, 1985).

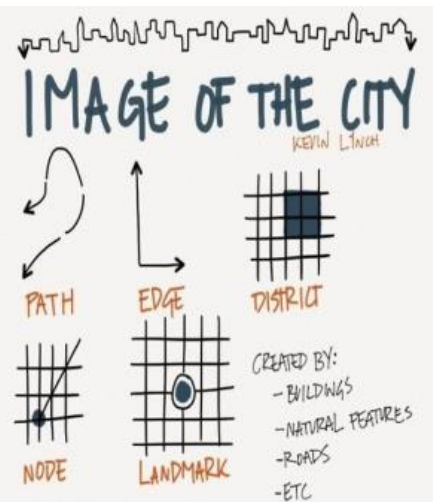

Figure 3. Elements of Forming City
(Source: https://tourism.binus.ac.id/, accessed in September 2018)

Form and mass of a building will create an image to a city and how the relationship between the masses is. There are several things related to the shape and mass of the building: Altitude; Context; Building Floor Coefficient; Basic Building Coefficients; Building Border Line; Style; Scale; Material; Texture; Color. Circulation element, such as road as a movement system should have a meaningful visual sequence. The road must have an interesting visual element and can give orientation to the driver and provide clarity of the environment. Open space involves elements of landscape, such as hard elements, parks and recreation spaces in the environments. The pedestrian way is not just beautification part of a design. It has some requirements to be used comfortably by pedestrians: (a) It should be safe, no cross circulation with the vehicle; (b) Easy to be used by promoting human scale pedestrian; (c) Clear access route and fun; (d) Have aesthetics like bench, streetlamp, trash can, etc. (Frick, 1998).

The building is a two-story building so rigid frame system is used. The system consists of reinforced concrete beams and columns. To keep the structure rigid, beams and column are used as support pillar (Figure 4) (Pynkyawati, 2015). 


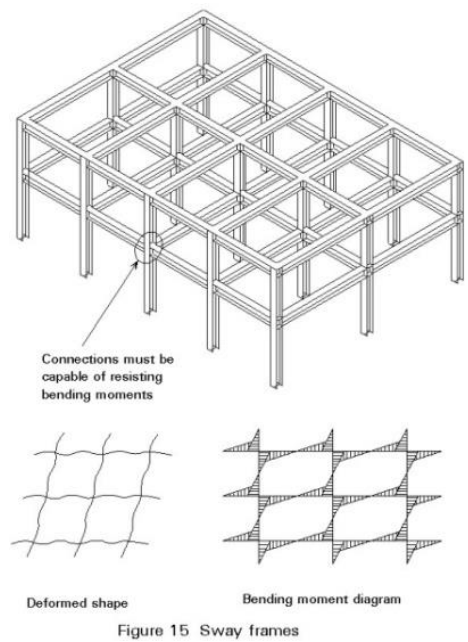

Figure 4. Frame System
(Source: https://myframe.co/frame-structure-system/, accessed on September 2018)

The system of clean water distribution for the building implements a general system. The system uses the lower reservoir as a medium to store water supplied by the local water company before being distributed to the upper reservoir by a booster pump. The lower reservoir is usually located below the basement and holds $2 / 3$ of the volume of water requirements while the upper reservoir is located on the roof and holds $1 / 3$ of the volume of water requirements. This system relies on gravity in the distribution of water (Figure 5) (Kodavasal, 2011).

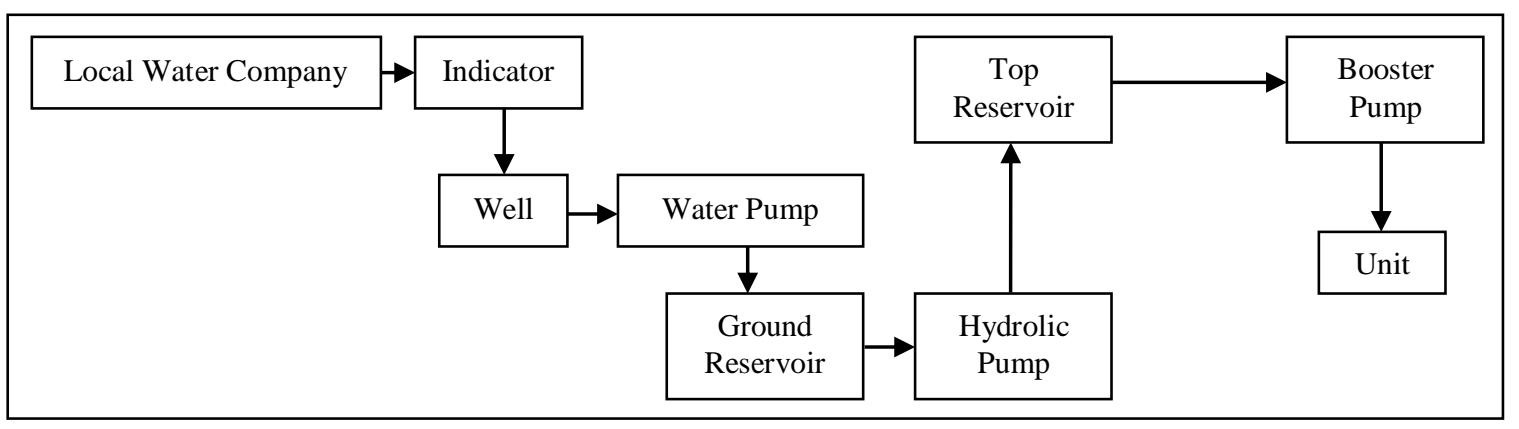

Figure 5. Clean Water Distribution System

(Source: Pynkyawati, I. T., \& Wahadamaputera, I. S., 2015)

For the waste, Sewage Treatment Plan (STP) system is used for dirty water distribution. The typical process in an STP consists of bar screen chamber, equalization tank, aeration tank, settling tank, clarifier water sump, sand filter, activated carbon filter and treater water tank (Figure 6) (Poerbo, 1992).

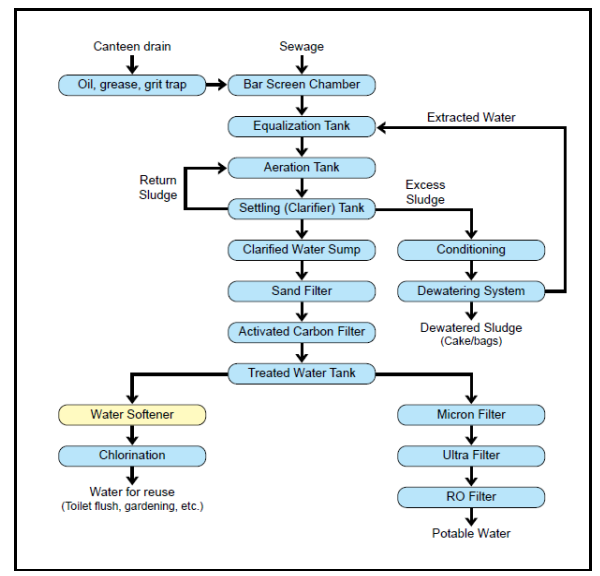

Figure 6. STP System

(Source: Kodavasal, A. S., 2011)
Electrical installation must pay attention to the load borne by the cable size. It is necessary to estimate in advance the total burden that will be needed (Poerbo, 1992). Electrical installations consist of: electric lighting; socket; building ventilation and air conditioning; Plumbing; vertical transportation; Kitchen Appliances; Special Equipment (Figure 7). 


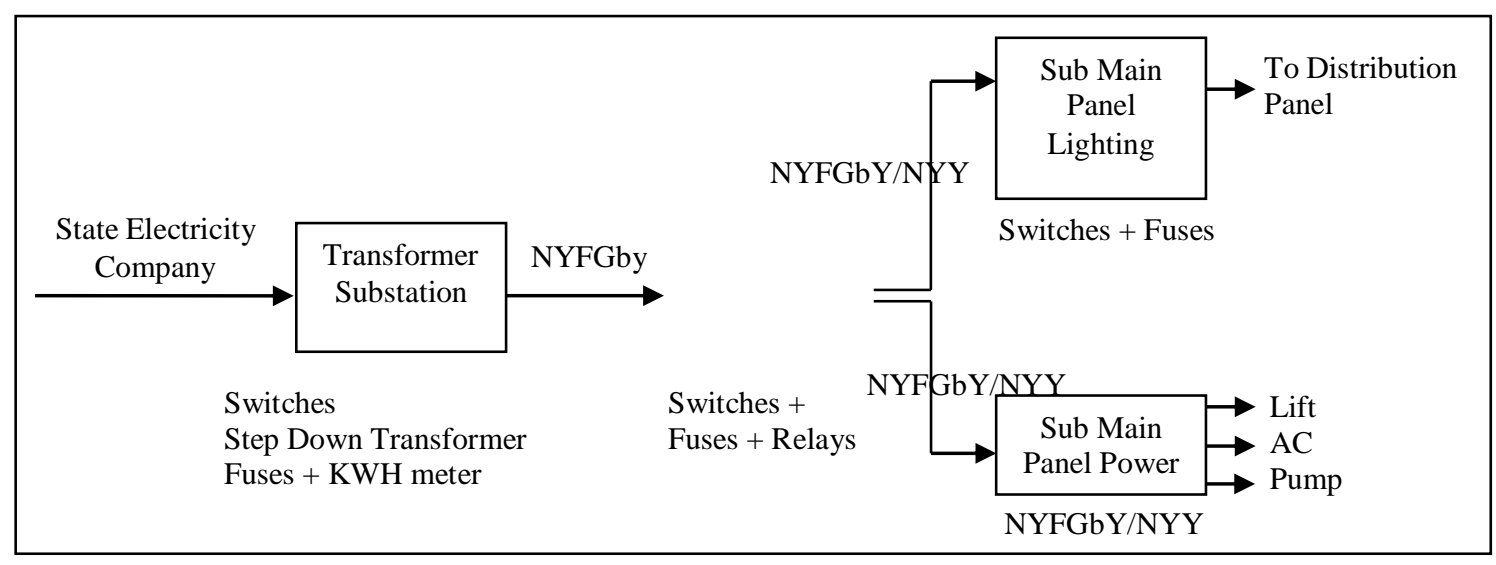

Figure 7. Electrical System

(Source: Poerbo, H., 1992)

\section{METHOD}

The design method that is applied in solving design problems uses a rational method (glass box) which has some stages such as situation exploring stage, the research stage, the problem-solving stage, the evaluation stage. The approach method used is the method of field studies, comparative studies of similar buildings, and literature studies. The collection method uses primary data obtained from field surveys and documentation as well as secondary data from the internet, published books, recorded or archived in general.

The criteria site selection is based on the direction of the development of Deli Serdang Regency that was established as an environmentally-oriented tourism center and by the District Spatial Plan. This location is suitable for the design location as it is met the criteria of the cultural park.

\section{RESULTS AND DISCUSSION}

The metaphor is implemented in the cultural park building, especially the museum. The basic theme concept of the cultural park is tangible metaphors. The purpose of the emphasis of metaphorical form on this building is to create an iconic museum so that it could enriched tourism destination and adding insight of local or international citizen about their culture.

Local wisdom issues are very significant in every design today. Therefore the outer spatial concept applies the concept of local wisdom. The local wisdom applied is not just about the site, but also within a radius of 500 meters. The orientation of the mass of cultural park is an important thing that should not be arbitrary. The museum mass orientation should be based on the concept of Feng Shui as the orientation influenced the building. Zoning on the site consists of several areas based on the traits or characteristic of the area (Figure 8).

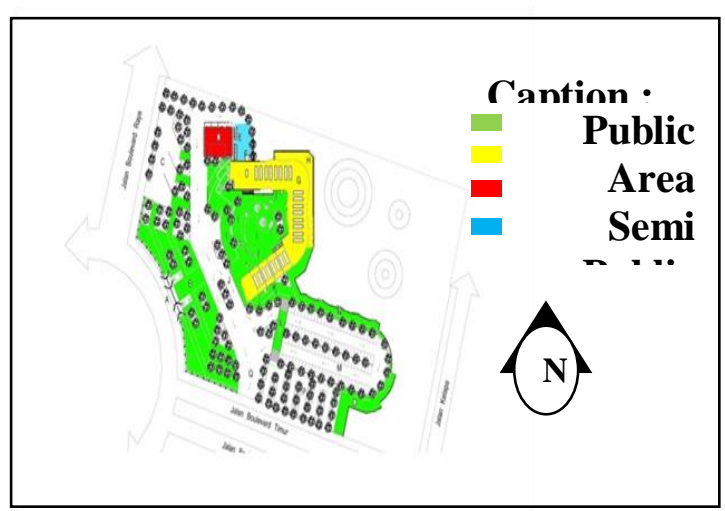

Figure 8. Exterior/ Siteplan Design Visualization

Good circulation minimizes cross circulation. To avoid cross-circulation, the vehicle lane and pedestrian lane are endeavored not to be in the same lane. Parking areas for four-wheeled vehicles are attempted to be designed around the mass to create a good view when car drivers enter the cultural park in response to the emphasis of metaphors form. The motorbike parking area is designed adjacent to the existing area where traders sell their foods. With the position of the motorbike parking area, it is expected to be a magnet to attract customers who want to eat food in this area to enter the museum area. In front of the museum, the plaza is provided a drop-off and pedestrian place that is wide and comfortable to accommodate the activities, such as jogging (Figure 9). 


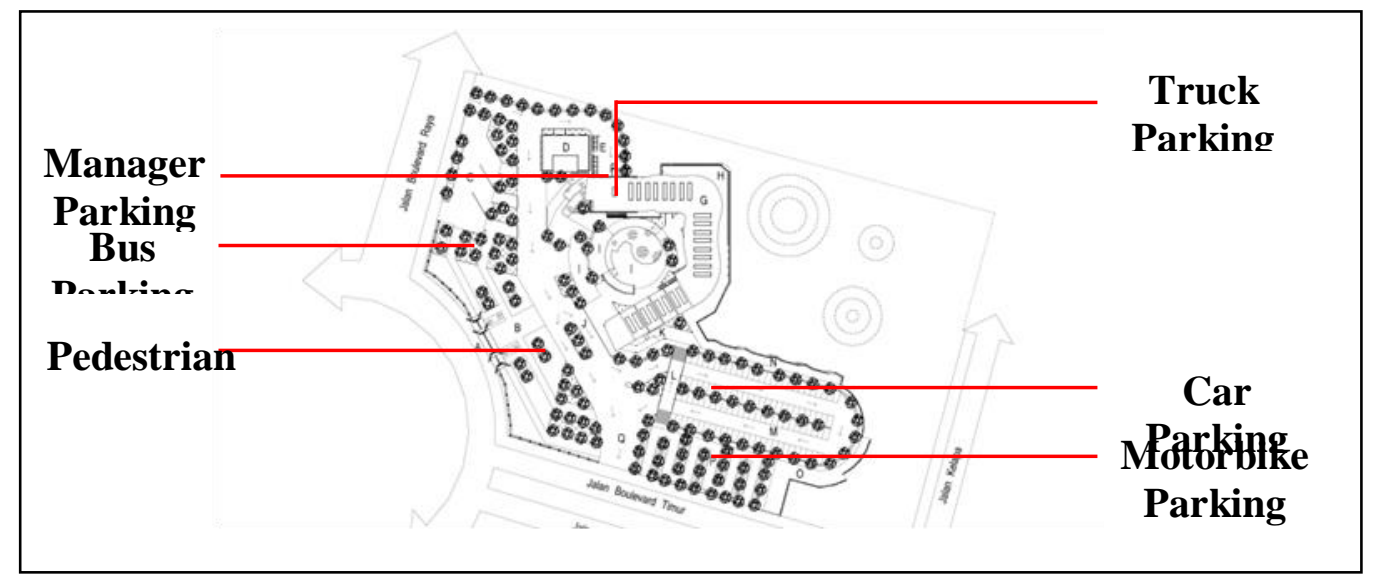

Figure 9. Circulation Visualization

A form of building mass must reflect the characteristics of the surrounding environment. Therefore, the author chose a mythical dragon animal form to represent Chinese. The dragon can see everything deep inside which makes it a symbol of wisdom and understanding. The wisdom is symbolized by a pearl ball which it holds on its claw or in its mouth which is guarded as a treasure. To seek wisdom, one must understand himself first.

The shape of the body is circular, forming a letter $\mathrm{U}$, emphasizing the long shape of the dragon. The upper scales are designed as skylights in the museum, and the side body scales are designed to form windows with certain patterns. Culture is an important thing that can be compared to a pearl ball that is gripped by a dragon. Understanding of local cultural identity is a reflection of wisdom. Therefore, the shape of a dragon gripping a pearl ball was chosen as the theme of the metaphor in designing the cultural park (Figure $10)$.

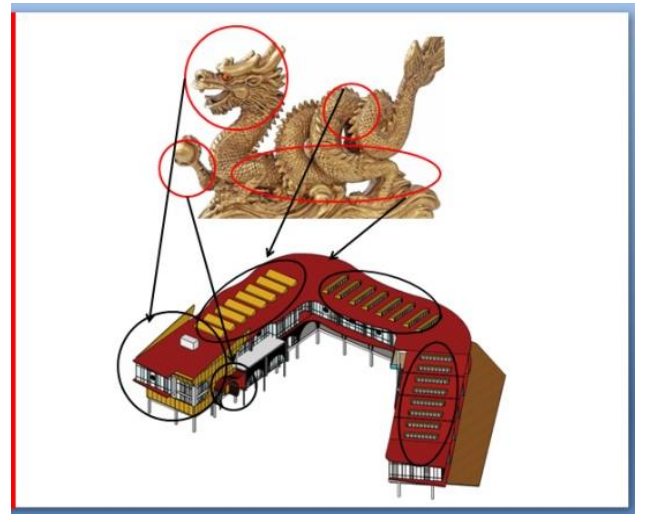

Figure 10. Mass Concept Visualization

The museum has two floors where the first floor in the left building is designed as a lobby area, audiovisual room, small library, toilet, service area, and café. The right building is designed with a declining concept such as a ramp which is an area of museums and souvenir shops. The second floor is a museum with a specific division of area according to the age, namely the era of Chinese entry, the Tjong brothers and the modern era. On the second floor, there is a warehouse, toilet and rest area with a fire lane (Figure 11).

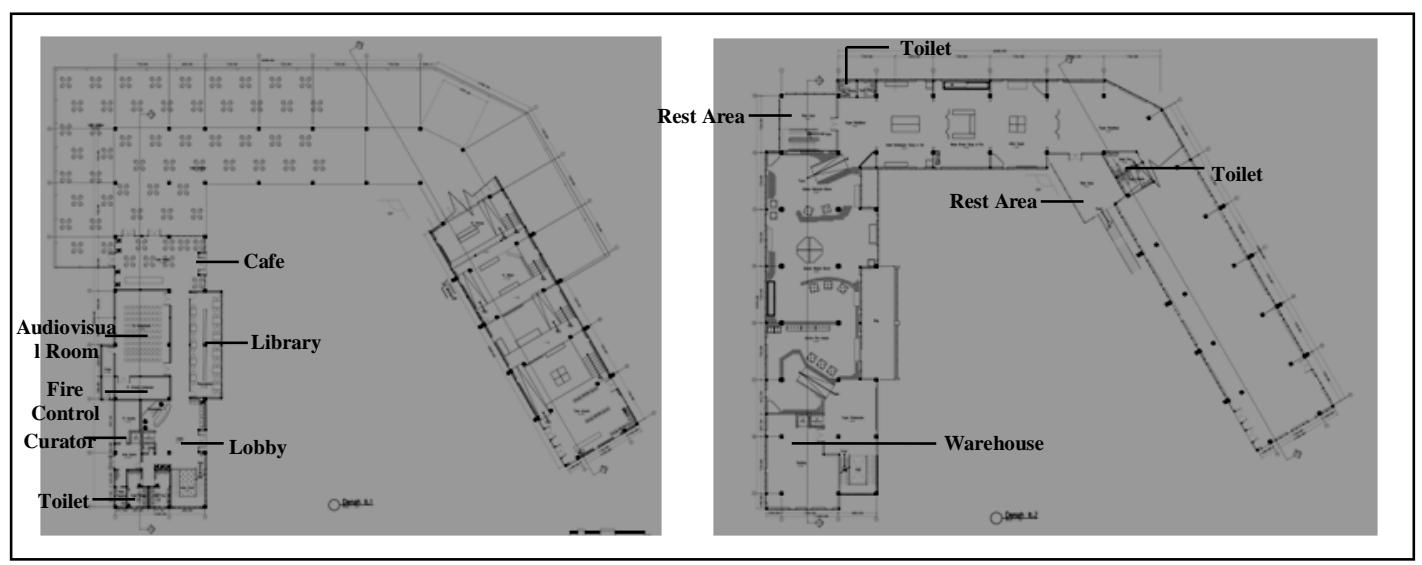


Figure 11. Inner Spatial Concept Visualization

\section{Structure}

The cultural park uses a system of reinforced concrete structures with a floating building system. Reinforced concrete structures are chosen because of the variety of shapes that can be formed, material derived from local materials and construction using low-energy power. The foundation used is the bore pile foundation because the soil conditions in the design area itself is an area surrounded by water as deep as about 1 meter (Figure 12).

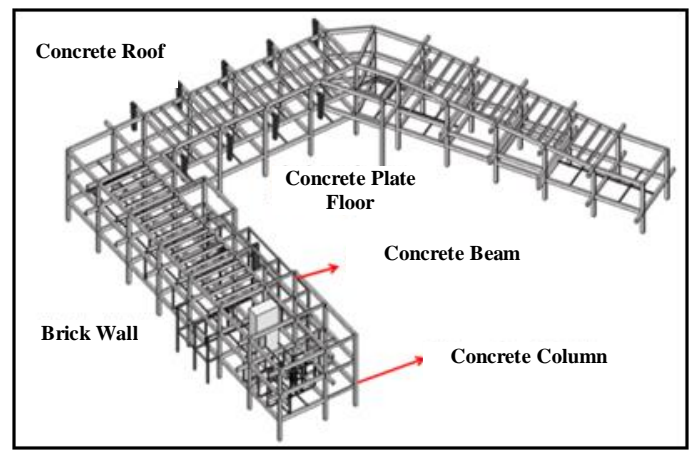

Figure 12. Structure Concept Visualization

\section{Utility}

The concept of utility includes a clean water distribution system, the waste distribution system, and electrical system. The source of the clean water supply comes from the water distributor company. The system uses the lower reservoir as a medium to store water supplied by the distributor before being distributed to the upper reservoir by a booster pump. This system relies on gravity in the distribution of water.

As for the grey water it comes from the floor drain, urinal, and sink will be recycled by the sewage treatment system which will be reused again for flushing or watering the plants. The discharge of heavy waste from the WC unit is directly channeled into the septic tank and then anaerobically described. Electrical system source comes from the state electricity company. The building used skylight for the interior lighting.

\section{D Impression}

The top view of the cultural park shows the shape of the Yin Yang. The Yin form is symbolized by the form of the museum, and the Yang form is symbolized by the form of the park and the parking area. The dragon shapes can be seen from four directions that result different view of a dragon (Figure 13).

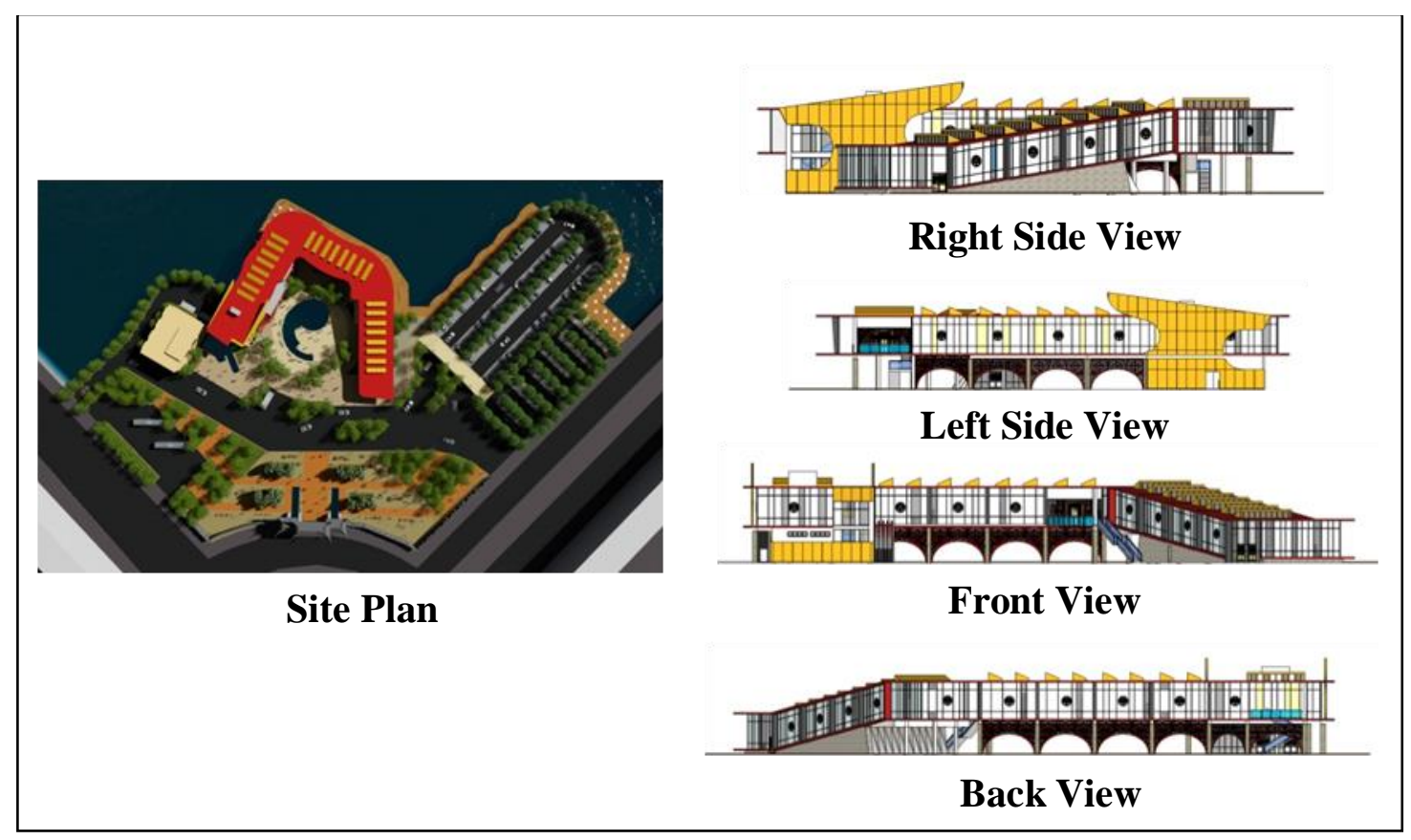

Figure 13. Site Plan and View Visualization 
The interior from each era of the museum will create different kind of atmosphere (Figure 14).

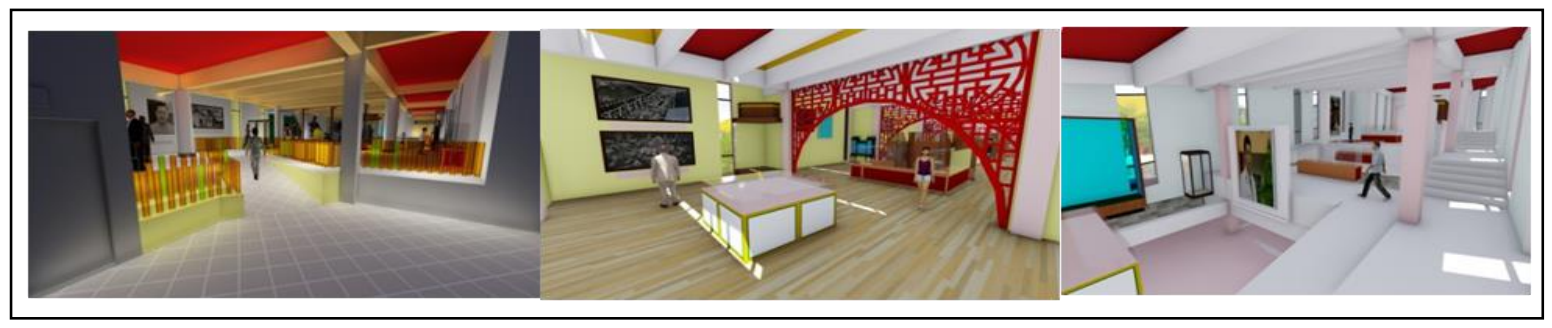

Figure 14. Interior Visualization

The exterior visualize the form of a mythical dragon animal form to represent Chinese. The Yin form is symbolized by the form of the museum, and the Yang form is symbolized by the form of the park and the parking area (Figure 15).

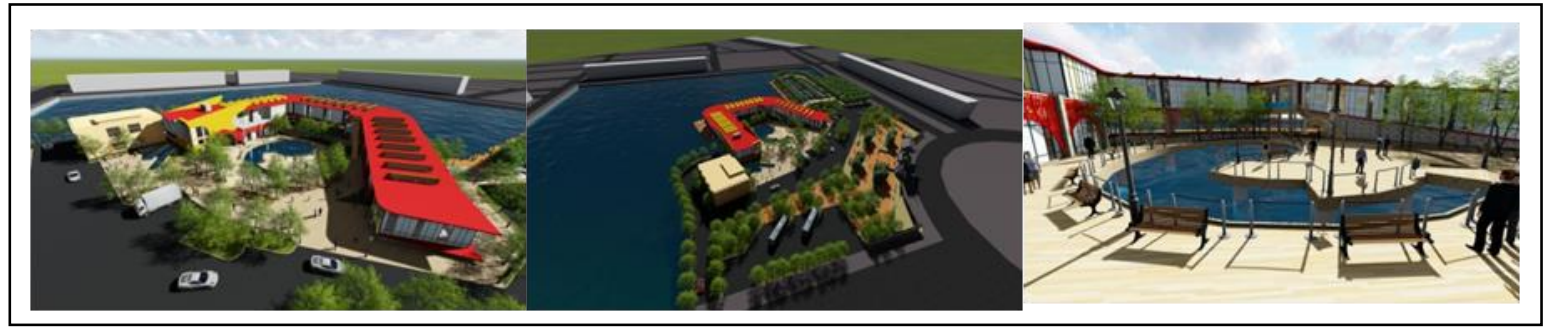

Figure 15. Exterior Visualization

\section{CONCLUSION}

The emphasis of metaphor in the cultural park building used the concept of tangible metaphors. The purpose of the emphasis of metaphorical form on this building is to create an iconic museum so that it could enriched tourism destination and adding insight of local or international citizen about their culture. A form of building mass must reflect the characteristics of the surrounding environment. Therefore, the author chose the dragon animal form to represent Chinese culture.

To avoid cross-circulation and to make a good circulation, the vehicle lane and pedestrian lane are distributed into a different lane. Fourwheeled vehicles parking area are attempted to be designed around the mass to create a good view while driving around the site. As for motorbike parking area is designed adjacent to the existing area where traders sold their foods and expected to be a magnet to attract customers to enter the museum area after a dig.

\section{Acknowledgment}

This article was prepared by researchers as a part of funding by Universitas Sumatera Utara to the City Government to dedicate expertise in the field of architecture based on local wisdom in planning and design

\section{REFERENCE}

Antoniades, A. C. (1990) Poetics of Architecture: Theory Of Design (Vol. 150) New York: Van Nostrand Reinhold 
De Chiara. J, (1990) Time-Saver Standards for Building Types. New York: McGrawHill.

Frick, H. (1998) Sistem Bentuk Struktur Bangunan. Yogyakarta: Kanisius.

Ganslandt, R. (1992) Handbook Of Lighting Design.

KBBI (2018) Pengertian Museum. (http://kbbi.web.id/) diakses 14 August 2018.

Kementrian Pendidikan (1991) Surat Keputusan Menteri Pendidikan dan Kebudayaan RI No. 0221/0/1991 Tentang Struktur Organisasi Taman Budaya. Sekretariat Kementrian. Jakarta: Sekretariat Kementrian.

Kodavasal, A. S (2011) he STP Guide : Design, Operation, Maintenance. Karnataka Pollution Control Board. (kspcb.gov.in/STP-Guideweb(Lo).pdf.) diakses 5 August 2018.

Lynch, K (1960) The Image of The City (Vol. 11). MIT Press.

Neufert, E (1980) Architect's Data Second (International) English Edition. London: Collins Professional and Technical Books.

Pane, I. F. \&. Harisdani. D. D. (2013) Kajian" Sense of Place" Terhadap Usaha Peningkatan Pariwisata Kota Medan.

Pynkyawati (2015) Utilitas Bangunan Modul Plumbing. GRIYA KREASI.

Poerbo, H (1992) Utilitas Bangunan. Jakarta: Djambatan.

Resmawat. W. I (2014) Fungsi Gedung Taman Budaya Jawa Timur Sebagai Wadah Aktivitas Seni Tradisional Jawa Timur Tahun 1978-1988. Avatara, 295.

Shirvani, H (1985) The Urban Design Process. Van Nostrand Reinhold Company. 